ECONOMIC, SOCIAL AND CULTURAL RIGHTS 


\title{
Economic, Social and Cultural Rights
}

\section{Progress and Achievment}

\author{
Edited by
}

Ralph Beddard

Senior Lecturer in Law,

University of Southampton

and

Dilys M. Hill

Reader in Politics,

University of Southampton

Palgrave Macmillan 
ISBN 978-1-349-21796-0

ISBN 978-1-349-21794-6 (eBook)

DOI 10.1007/978-1-349-21794-6

(c) Ralph Beddard and Dilys M. Hill 1992

Softcover reprint of the hardcover 1st edition 1992

All rights reserved. For information write:

Scholarly and Reference Division

St. Martin's Press, Inc., 175 Fifth Avenue,

New York, N.Y. 10010

First published in the United States of America in 1992

ISBN 978-0-312-05742-8

Library of Congress Cataloguing-in-Publication Data

Economic, social, and cultural rights : progress and achievement / edited by Ralph Beddard and Dilys M. Hill.

p. $\mathrm{cm}$.

Papers from two workshops held in Mar. and Sept. 1988 and sponsored by the Human Rights Group of the Centre for International Policy Studies, at the University of Southampton

Includes index.

ISBN 978-0-312-05742-8

1. Human rights-Congresses. I. Beddard, Ralph II. Hill, Dilys M. III. University of Southampton. Centre for International Policy Studies. Human Rights Group.

JC571.E35 1992

323-dc20

90-9132

CIP 


\section{Contents}

The Mountbatten Centre for International Studies vii

Preface viii

Acknowledgements ix

Workshop Participants $\quad$ x

Notes on the Contributors xii

\section{PART I RIGHTS AND NEEDS}

1 Rights and their Realisation 1

Dilys M. Hill

2 A Defence of Welfare Rights 22 Raymond Plant

3 The Realisation and Implementation of 47 Economic, Social and Cultural Rights Julia Häusermann

4 Economic, Social and Cultural Rights: The Development of Governments' Views, 1941-88 Sally Morphet

5 Justiciability Re-examined 93 Michael K. Addo

\section{PART II CONTEMPORARY PUBLIC POLICY}

6 Rights and Performance: Economic and 
7 Universal Rights and Public Policy: The Case for Equal Opportunity

Ian Forbes

8 The European Social Charter: Employment, 153 Unions and Strikes

Vivien J. Shrubsall

9 Implementing the Right to Education in

England

Julian Lonbay

10 Recognising a Right to Health

184

Jonathan Montgomery

Index 


\section{The Mountbatten Centre for International Studies}

The Mountbatten Centre for International Studies originated in the Centre for International Policy Studies which was established within the Department of Politics in the University of Southampton in 1983. It brings together members of the Departments of Adult Education, History, Law and Politics to foster interdisciplinary and multi-disciplinary research into the domestic and external dimensions of policy.

Members of the Centre are involved in research on a wide range of issues. Recently published works include volumes on the Falklands War, the Carter and Reagan Presidencies, the European Community, Human Rights, intervention, the international nuclear non-proliferation regime and the military use of nuclear energy in the United Kingdom. A major programme of research involving Centre members has investigated problems of North-South relations in the 1990s, using funds provided by the Ford Foundation of the United States. This has involved the Centre being granted observer status at international diplomatic conferences.

The Centre also sponsors research workshops and symposia on a range of subjects; recent topics have been human rights and foreign policy (aided by a grant from the Nuffield Foundation); nuclear non-proliferation policies in the 1990s (funded by the Ford Foundation), and information technology (funded by the Fulbright Commission).

Links have been established with the Centre d'Histoire Militaire of the University of Montpellier, and the Fondation Pour les Etudes de Defense Nationale, Paris. The Centre also participates in the work of the team on Political Culture in Eastern Europe at the Ecole des Hautes Etudes en Sciences Sociales and the Fondation Nationale des Sciences Politiques, Paris. Members of the Centre have participated in the work of the European Science Foundation, the European University Institute and the International Commission for the History of International Relations. 


\section{Preface}

In 1988 the Human Rights Group of the Centre for International Policy Studies, Department of Politics, University of Southampton, held two workshops on Economic, Social and Cultural Rights. A total of 35 participants were involved in the two workshops. The first, entitled Are Social and Economic Rights Human Rights? Are They Justiciable? explored the philosophical and universal aspects of the issues and related them to national and international rights' regimes. The second workshop, Universal Rights and Public Policy, examined specific policy areas: health, education, equal opportunities and race relations, and the employment aspects of the European Social Charter. These concerns are reflected in the papers published in this volume. In addition, there was lively debate at the workshops on the issues presented in Sir James Fawcett, QC's session on 'The Place of the Judicial Process in Human Rights', with special reference to the European Commission on Human Rights, on Benedict Kingsbury's 'International Law and the Rights of Indigenous Peoples' and on Laurence Lustgarten's 'Advancing Equality for Ethnic Minorities: The Experience of the Race Relations Act 1976'. These debates are reflected in the present volume in the editorial chapters by Ralph Beddard and Dilys Hill. Part I covers the discussions and presentations on rights and their realisation, while Part II considers progress and achievement in a number of contemporary issue areas with particular reference to the United Kingdom.

The special feature of the Study Group and its workshops continues to be the opportunity it gives for academics, lawyers, public servants and activists, both from Britain and further afield, to exchange ideas and to advance knowledge and understanding. Membership of the Study Group is open to all those with a professional or academic interest in human rights; enquiries should be addressed to either Ralph Beddard or Dilys Hill. 


\section{Acknowledgements}

The editors would like to thank Mrs K. M. Pack for her invaluable help in the preparation of the manuscript. 


\section{Workshop Participants}

Two Workshops on Economic, Social and Cultural Rights were held in the University of Southampton in March and September 1988. The following people participated in one or both of the Workshops:

Michael Addo, Department of Law, Staffordshire Polytechnic Susan Atkins, Faculty of Law, University of Southampton Karen Babbage, University of Southampton

Jill Barrett, School of Oriental and African Studies, University of London

Ralph Beddard, Faculty of Law, University of Southampton Alan Brier, Department of Politics, University of Southampton Sufian Bakunira, School of Law, University of Warwick Peter Calvert, Department of Politics, University of Southampton Simon Crow, University of Southampton Rose D'Sa, Commonwealth Secretariat

Sir James Fawcett, QC [President, European Commission on Human Rights, 1972-81]

Ian Forbes, Department of Politics, University of Southampton

Françoise Hampson, School of Law, University of Essex

Julia Häusermann, Director, Rights and Humanity

Dilys Hill, Department of Politics, University of Southampton Benedict Kingsbury, Exeter College, Oxford Julian Lonbay, Faculty of Law, University of Birmingham Laurence Lustgarten, School of Law, University of Warwick Jeremy McBride, Faculty of Law, University of Birmingham Dominic McGoldrick, Faculty of Law, University of Liverpool Jonathan Montgomery, Faculty of Law, University of Southampton Sally Morphet, Foreign and Commonwealth Office Bushra Musa, Bangladesh/Commonwealth Secretariat Raymond Plant, Department of Politics, University of Southampton Martin Raven, Foreign and Commonwealth Office Margherita Rendel, Institute of Education, University of London Michael Rubenstein, Editor, Equal Opportunities Review Vivien Shrubsall, Department of Law, University of Nottingham John Simpson, Department of Politics, University of Southampton 
Peter Slinn, School of Oriental and African Studies, University of London

Caroline Thomas, Department of Politics, University of Southampton

Katarina Tomasevski, The Danish Center of Human Rights, Copenhagen

Rachel Trost, Faculty of Law, University of Southampton

Rachel Walker, Department of Politics, University of Southampton Anthony Walters, Department of Philosophy, University of Southampton 


\section{Notes on the Contributors}

\section{THE EDITORS}

Ralph Beddard is Senior Lecturer in Law, University of Southampton, and Tutor for Postgraduate Students. He is the author of Human Rights and Europe.

Dilys H. Hill is Reader in Politics, University of Southampton and Director of the Centre for International Policy Studies. She is the editor of Human Rights and Foreign Policy and author and co-editor of The Carter Years: The President and Policy Making (with Glenn Abernathy and Phil Williams) and of The Reagan Presidency: An Unfinished Revolution? (with Raymond A. Moore and Phil Williams).

\section{THE OTHER CONTRIBUTORS}

Michael K. Addo is lecturer in Law, Staffordshire Polytechnic Ian Forbes is lecturer in Politics, University of Southampton Julia Häusermann is an international human rights lawyer and Director of Rights and Humanity, an international humanitarian movement

Julian Lonbay is lecturer in Law, University of Birmingham Jonathan Montgomery is lecturer in Law, University of Southampton

Sally Morphet is Head of the International and Commonwealth Section, Research Department, Foreign and Commonwealth Office Raymond Plant is Professor of Politics, University of Southampton Vivien Shrubsall is lecturer in Law, University of Nottingham 